\title{
DISCOURAGED OR ADDED WORKER EFFECT: WHICH ONE PREVAILS IN THE POLISH LABOUR MARKET?*
}

\author{
Ewa GAŁECKA-BURDZIAK - Robert PATER \\ (Received: 14 July 2015; revision received: 10 September 2015; \\ accepted: 27 October 2015)
}

\begin{abstract}
We test whether the discouraged worker or added worker effect prevails in the Polish labour market. The discouraged worker effect implies that the participation rate is procyclical with respect to the GDP and countercyclical with respect to the unemployment rate. The added worker effect yields contrary findings. We analyse the period 1994-2014 with quarterly data. We focus on the working age population, both males and females. We apply a range of methods to obtain robust results, some of which have never been employed to resolve this problem. They include ad hoc filtration, spectral analysis, unobserved component model, time-varying parameter model, and frequency domain regression. The results indicate that the added worker effect prevails in most of the business cycle frequencies. It is significant and varies over time. It is true for both males and females. It is considerably stronger in contractions than in expansions. In low business cycle frequencies, the discouraged worker effect prevails. Although the last case is rare, it proves the heterogeneity of labour force behaviour over the business cycle.
\end{abstract}

Keywords: discouraged worker effect, added worker effect, unobserved component models, frequency domain regression, business cycle, Poland

JEL classification indices: C22, J22

* We thank Luca Benati for providing us with the program written in Matlab to compute the band spectrum regression and Michał Gradzewicz for help in the computations.

Robert Pater, corresponding author. Head of the Department of Macroeconomics, University of Information Technology and Management, Rzeszow, Poland. E-mail: rpater@wsiz.rzeszow.pl

Ewa Galecka-Burdziak, Assistant Professor at the Collegium of Economic Analysis, Department of Economics I, Warsaw School of Economics, Warsaw, Poland. E-mail: eburdz@sgh.waw.pl 


\section{INTRODUCTION}

In this study, we analyse whether the discouraged worker effect or the added worker effect characterises the Polish labour market. Each one affects the cyclicality of the participation rates differently. We primarily use methods rarely used in analysing this issue, but compare the findings using the general methods. Discouraged workers and additional workers are marginally attached to the labour force. Their movements in the labour market affect the labour force and certain economic indicators. If we identify the discouraged worker effect or the added worker effect, we will be able to formulate labour market policy recommendations aimed at increasing labour force participation.

Discouraged workers are those who have demonstrated some labour force attachment. These individuals have been seeking work during the previous 12 months, but not in the last 4 weeks due to some reasons. Still, they want a job and are ready to start working. If the reasons for not seeking work are job market related, we can expect procyclical activity rates (Finegan 1981). From a microeconomic perspective, the added worker effect (or the additional worker effect) expresses changes in the activity rates (mostly those of females) associated with the partners' job losses (Gong 2010). Thus, if the breadwinner loses his job, the partner increases her labour supply to compensate income loss. We mirror this effect in the macroeconomic perspective and we define the added worker effect in terms of the aggregate changes in participation rates during the business cycle. If the participation rate is counter-cyclical, we perceive it as the added worker effect.

Benati (2001) and Gałecka-Burdziak (2015) reviewed the discouraged worker effect studies. This effect occurs primarily among females and older workers. In the aggregate analyses, the cyclicality of the participation rates is analysed. In the microeconomic perspective, the discouraged worker effect arises when individuals choose to be inactive to evade unemployment or when they perform passive job search methods due to their low employability. The effect is usually asymmetric and is stronger in recessions than expansions. Added worker effect analyses most often look at the activity rates of females and males within the household and their changes during the business cycle. This effect is often studied within the family labour supply model. Gong (2010) provided a literature survey and finds that it is easier to increase intensive labour supply than extensive one. Filatriau - Reynes (2012) analysed the impact of the unemployment rate on labour force participation rates by age and sex breakdown. They find clear added worker effect for females. 
The literature lacks discouraged and added worker effects analyses in the Polish labour market - either concerning the magnitude or the cyclical properties. Some attempts have been made, though. Allison - Ringold (1996) suggested that an increase in the number of discouraged workers reflected the outflow from activity at the beginning of 1990s. Kucharski (2002) computed mean transition rates between employment, unemployment, and inactivity. He claimed that people refrained from an active job search due to poor employment chances and this resulted in a decreasing outflow rate from inactivity to either employment or unemployment. Góra (2005) claimed that some of those who did not actively seek work were in fact discouraged. When we regard these people as unemployed, we overestimate the problem of unemployment and underestimate the problem of low participation rates. Gałecka-Burdziak $(2011,2013)$ presented quarterly Markov transition matrices for the periods 2007-2008 and 2000-2010. The outflow rate from unemployment to inactivity approximated the discouraged worker effect (although this flow includes workers who exit the market for different reasons). Gałecka-Burdziak (2011) estimated the logistic regression to identify factors that influence the outflow from unemployment to inactivity. She found that females and older workers were more likely to exit the market.

In Section 2 we present the data. We show the behaviour of the main variables during the analysed period. We extract cyclical fluctuations from the time series and show their properties. We use non-parametric methods, namely ad hoc filtration with spectral analysis, and a parametric method, namely unobserved component models, UCM (Harvey 1989). In Section 3, we model the relationship between either the participation rate, or the discouraged worker index and the macroeconomic indicator. We use the frequency domain regression technique according to the algorithm proposed by Benati (2001) and unobserved component models with time-varying parameters, TVP (Durbin - Koopman 2012). The frequency domain regression allows for analysing relations between certain frequencies of the chosen variables, which is appropriate for cyclical periodicity analysis. Unobserved component models are used to model the relation in the time domain, but taking into account the extraction of, among others, the trend and the cycle. Compared to the UCM estimates in Section 2, the TVP approach allows for testing and modelling stochastic parameters. We use this to examine possible changes in the elasticity of discouraged or added worker effect over time. These methods, especially UCM, TVP, and spectral analysis, are rarely used in labour market analyses, so this is our contribution to the robustness of the results in this subject matter. In Section 5, we discuss the results, and we compile our findings in Section 6. 


\section{LABOUR MARKET ACTIVITY IN THE BUSINESS CYCLE}

We analyse labour force participation rates and the discouraged worker index. We define the discouraged worker index as the ratio of the number of discouraged workers ${ }^{1}$ to the respective population. We use quarterly data for the period 1994-2014. We analyse females and males separately. We use three macroeconomic indicators: gross domestic product (GDP, in millions of PLN, chain linked volumes, reference year 2005, data for the period 1995-2013), capacity utilisation in the manufacturing sector, and the unemployment rate.

During 1995-2014, Poland did not experience a recession, understood as two consecutive quarters of negative GDP growth (Figure 1). It went through five deviation (from trend) cycles with mild expansions and contractions. The highest GDP growth occurred during the late 1990s and 2005-2007. In relative terms, the most severe contractions happened in 2000-2001 and during the 2007-2010 world crisis. Even then, Poland maintained a positive annual GDP growth. Another measure of economic fluctuations is that capacity utilisation in manufacturing was not changing so rapidly. It was less prone to weaker business fluctuations. It recorded more profound fluctuations, i.e. classical cycles. ${ }^{2}$ According to them, major cyclical troughs occurred in Poland around 2000 and 2009, and the most prominent peak in the pre-crisis period was in 2007. Unemployment rate is the last reference indicator we chose. It directly shows the effects of the business cycle on the labour market. Similarly to capacity utilisation, it primarily expressed major economic fluctuations around natural unemployment. Labour force mobility was limited and it did not adjust to short-term fluctuations. The unemployment rate also lagged in comparison to the other macroeconomic aggregates.

Activity rates exhibited mainly a long-run tendency, with a small variance of fluctuations (Figure 2). Fluctuations were more visible in the case of females than males. The main breakthrough in the general tendency was a trough in the economic activity of males in 2004 and of females in 2007. It coincided with the decrease in the working age population, which began in 2005 for both sexes. Additionally, since then, the number of economically active males and females has started to rise. Peaks in the mild fluctuations of the activity of females can be seen in 2001 and 2011. The number of discouraged workers in the working age population (relative to the overall population in that age) generally grew

1 The Central Statistical Office (CSO) defines discouraged persons as a group specified among the economically inactive. These are the persons not seeking work because they are convinced that they will not find it (CSO 2015).

2 Classical cycles are the ones that are visible and identified without removing the trend (Zarnowitz - Ozyildirim 2006). They are longer than deviation cycles and fall into the lower interval of business cycle frequency (Pater 2014). 

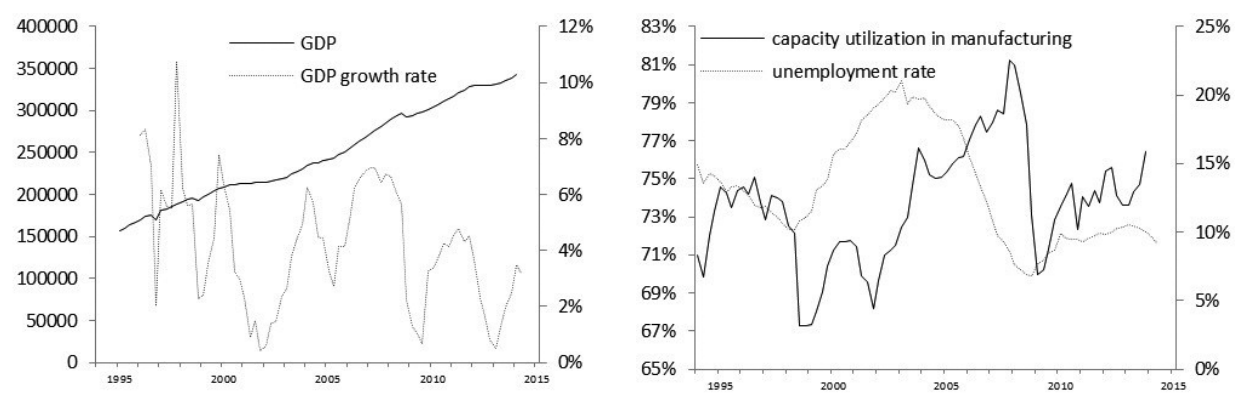

Figure 1. Chosen macroeconomic aggregates

Note: Time series were seasonally adjusted, GDP volumes in millions of PLN. Unemployment rate presented on the right axis (right plot).

Source: Eurostat, Central Statistical Office of Poland.
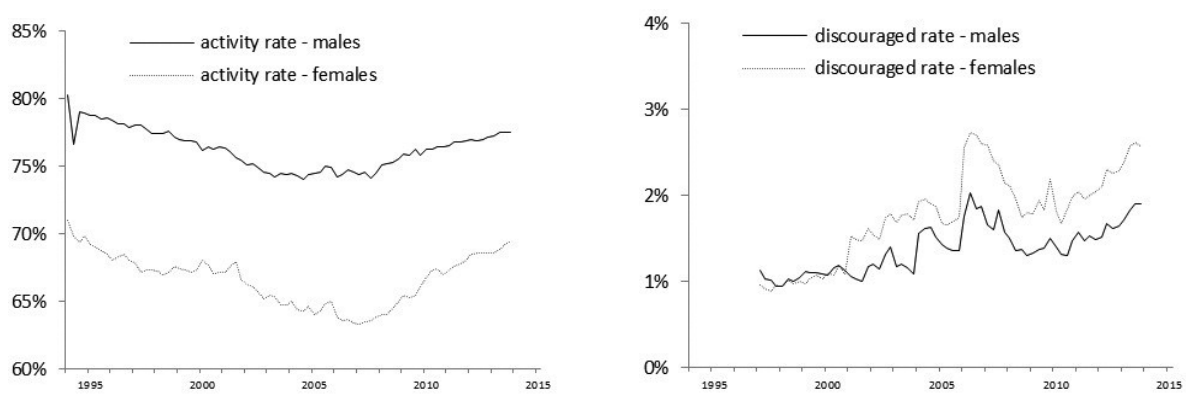

Figure 2. Activity rates and rates of discouraged workers for the working age - males and females Note: Time series were seasonally adjusted.

Source: Eurostat, Central Statistical Office of Poland.

until 2007. After the pre-crisis cyclical peak in the economy, it decreased and remained lower during the crisis. With the faster growth of the Polish economy, again it started to rise.

The presence of unit root in the series was verified using the ADF and PhillipsPerron tests (Table 1). The tests' results indicated that the analysed time series were I(1), i.e. they contained the long-run non-stationary component.

We applied the parametric approach to the business cycle extraction. We estimated unobserved component models, taking into account the non-stationarity of the time series. Having determined the cyclical components (Figure 3), we computed the coefficients of variation as a measure of the business cycle relative amplitude $^{3}$ (Table 2).

3 The coefficient of variation was calculated as $\mathrm{V}_{\mathrm{c}, \mathrm{t}}=\frac{\mathrm{s}_{\mathrm{c}, \mathrm{t}}}{1 / \mathrm{T} \sum_{\mathrm{t}=\mathrm{I}}^{\mathrm{T}} \mathrm{y}_{\mathrm{t}}} 100$, where $\mathrm{s}_{\mathrm{c}, \mathrm{t}}$ is the standard deviation of the cyclical component of the "raw" time series $\mathrm{y}_{\tau}$. 
Table 1. The ADF and Phillips-Perron tests' statistics

\begin{tabular}{lcc}
\hline Variable & ADF test statistics & $\begin{array}{c}\text { Phillips-Perron test } \\
\text { statistics }\end{array}$ \\
\hline & & \\
\hline Male activity rate & & -17.95 \\
Female activity rate & -22.35 & -7.75 \\
Male discouraged workers rate & -7.75 & -8.27 \\
Female discouraged workers rate & -8.02 & -8.09 \\
GDP & -8.09 & -5.47 \\
Capacity utilisation in the manufacturing sector & -1.85 & -6.81 \\
Unemployment rate & -6.81 & -5.63 \\
\hline & -3.03 & \\
\hline Male activity rate & & -2.77 \\
Female activity rate & -2.79 & -1.77 \\
Male discouraged workers rate & -1.74 & -1.44 \\
Female discouraged workers rate & -1.45 & -1.32 \\
GDP & -1.32 & -0.17 \\
Capacity utilisation in the manufacturing sector & -0.15 & -2.33 \\
Unemployment rate & -2.67 & -1.25 \\
\hline
\end{tabular}

Source: Own calculation.
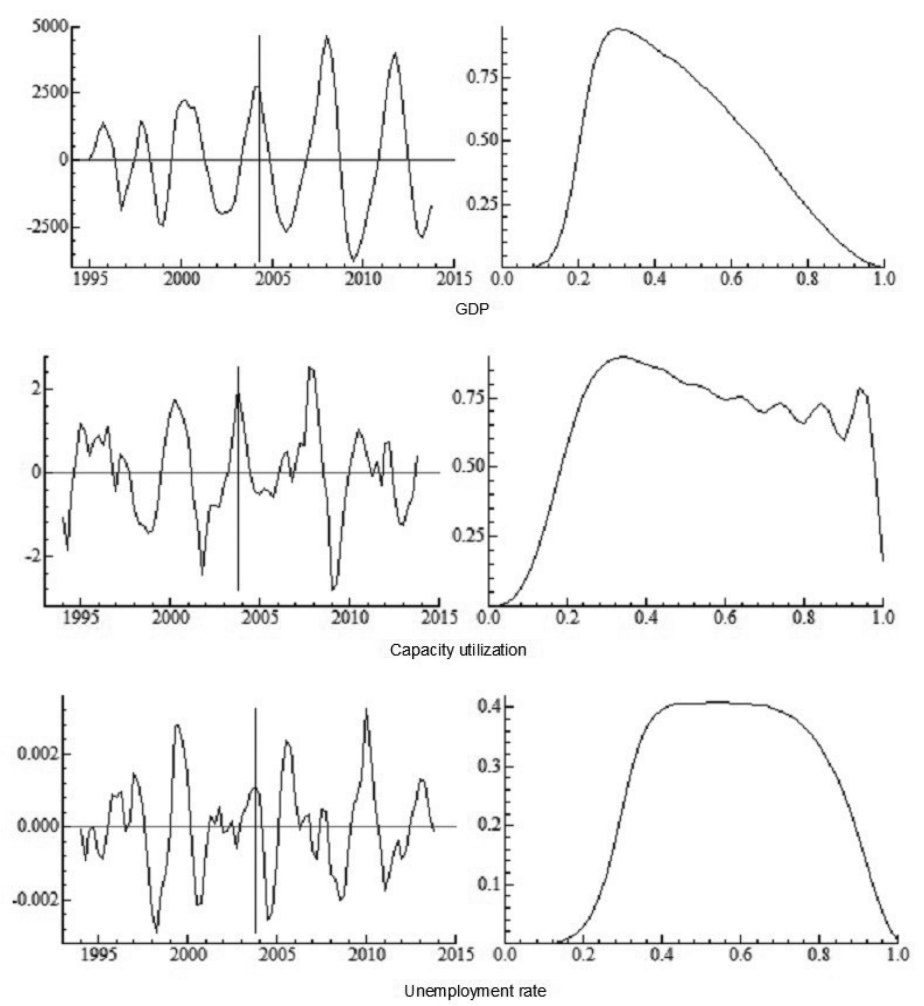

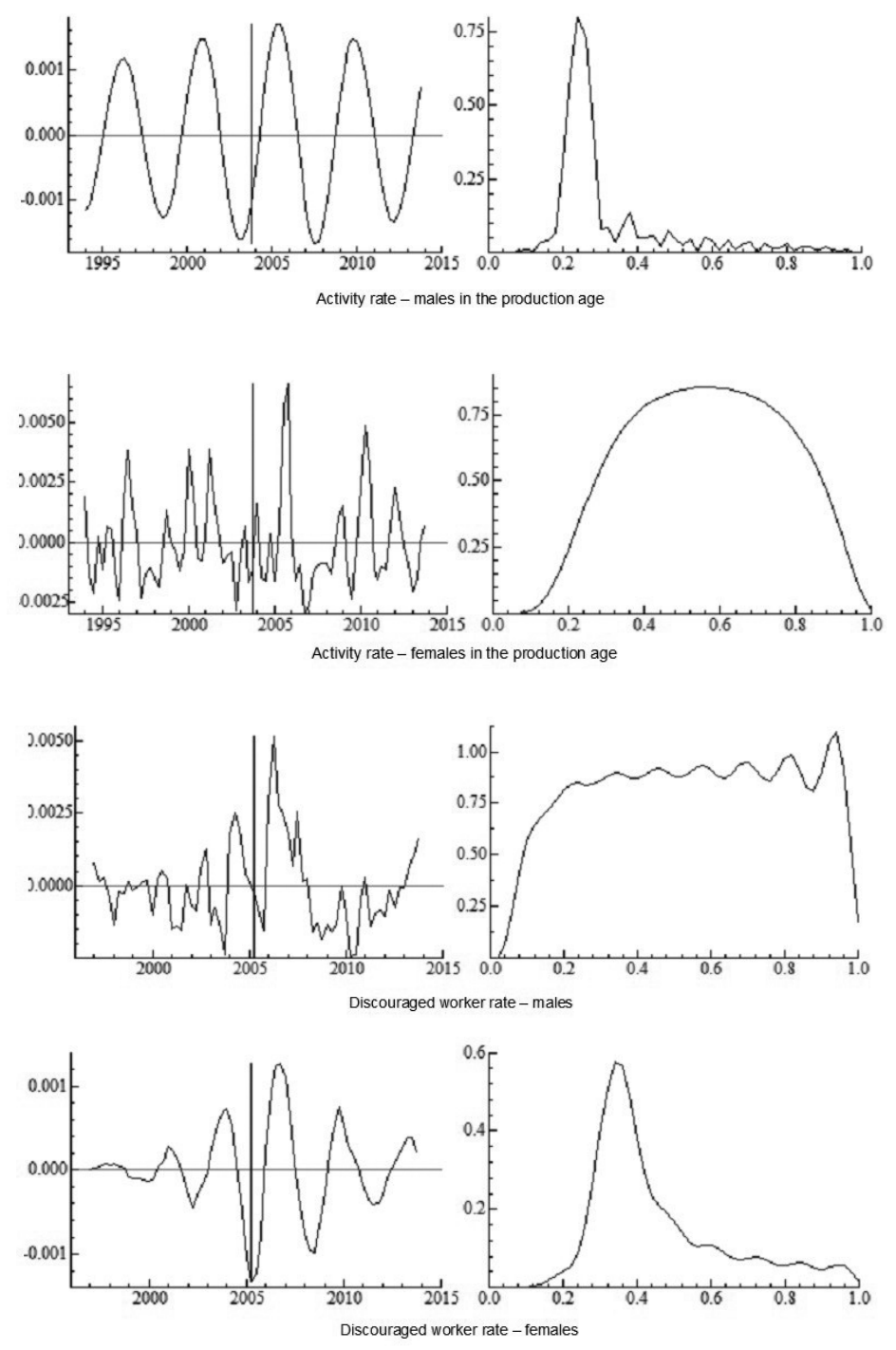

Figure 3. Cyclical components (left chart) and gain functions (right chart) of cycles estimated using the unobserved component models

Source: Own calculation. 
Table 2. Cyclical characteristics of the activity rates, discouraged worker rates and chosen macroeconomic reference indicators

\begin{tabular}{lccccc}
\hline Cyclical component & $\begin{array}{c}\text { Coefficient } \\
\text { of cyclical com- } \\
\text { ponent variation } \\
(\mathrm{UCM})\end{array}$ & $\begin{array}{c}\text { Model re- } \\
\text { strictions } \\
(\mathrm{UCM})\end{array}$ & $\begin{array}{c}\text { Damping } \\
\text { Factor } \\
(\mathrm{UCM})\end{array}$ & $\begin{array}{c}\text { Period } \\
\text { in years } \\
(\mathrm{UCM})\end{array}$ & $\begin{array}{c}\text { Period } \\
\text { in years } \\
(\mathrm{CF})\end{array}$ \\
\hline GDP & $0.8 \%$ & $\sigma_{\eta}=0$ & 0.925 & 3.74 & 3.75 \\
$\begin{array}{l}\text { Capacity utilisation in } \\
\text { manufacturing sector }\end{array}$ & $1.5 \%$ & $\sigma_{\varepsilon}=0$ & 0.867 & 3.48 & 3.50 \\
$\begin{array}{l}\text { Unemployment rate } \\
\text { Activity rate }- \text { males, }\end{array}$ & $1.0 \%$ & - & 0.838 & 3.38 & 5.00 \\
$\begin{array}{l}\text { working age } \\
\text { Activity rate }- \text { females, }\end{array}$ & $0.1 \%$ & $\sigma_{\eta}=0$ & 0.993 & 4.56 & 3.50 \\
$\begin{array}{l}\text { working age } \\
\begin{array}{l}\text { Discouraged rate }- \text { males, } \\
\text { working age }\end{array}\end{array}$ & $0.3 \%$ & $\sigma_{\eta}=0$ & 0.510 & n.a. & 5.25 \\
$\begin{array}{l}\text { Discouraged rate }- \text { females, } \\
\text { working age }\end{array}$ & $10.3 \%$ & $\sigma_{\varepsilon}=0$ & 0.694 & n.a. & 3.00 \\
\hline
\end{tabular}

Note: ${ }^{\text {a }}$ Restrictions on variances of the disturbance terms, notation as in Harvey (1989): $\sigma_{\eta}=0$ means a smooth trend with stochastic cycle, $\sigma_{\varepsilon}=0$ means a random walk with stochastic cycle, - means a local linear trend with stochastic cycle. n.a. means too far from deterministic to determine reliably.

Source: Own calculation.

The female activity rate was modelled by a smooth trend with the stochastic cycle. This form indicated that the female participation rate's long-run changes were mainly one-directional, almost deterministic. The trend was downward sloping between 1994 and 2007, and upward sloping since then. The cycles were short and irregular. For males, the model also reduced to the smooth trend, but with a cycle that was close to deterministic. The cycle was longer than in the case of macroeconomic indicators and lasted 4.56 years on average.

The random walk model with the stochastic cycle most appropriately described male and female discouraged worker indices. The data-generating process implied that these time series did not exhibit any deterministic trend; they tended to fluctuate, although these rates increased over time. The female cycles' mean duration was 3.14 years. The cycles of female discouraged worker rate were closer to the deterministic than those of males.

The relative amplitudes of the activity rates' cyclical components were lower than in the case of macroeconomic indicators. This implied the weak cyclicality of the labour force in Poland. Females were relatively more susceptible to the business cycle than males. The discouraged worker indices experienced a higher relative amplitude. However, the business cycle did not seem to be the most important reason for discouragement, especially for females. We applied the band- 
Table 3. Correlation coefficients between cyclical components calculated on the basis of the HP filter estimates

\begin{tabular}{lcccc}
\hline & $\begin{array}{c}\text { Male activity } \\
\text { rate }\end{array}$ & $\begin{array}{c}\text { Female activity } \\
\text { rate }\end{array}$ & $\begin{array}{c}\text { Male } \\
\text { discouraged } \\
\text { worker rate }\end{array}$ & $\begin{array}{c}\text { Female } \\
\text { discouraged } \\
\text { worker rate }\end{array}$ \\
\hline GDP & 0.016 & $0.261^{*}$ & $-0.207^{*}$ & -0.046 \\
Capacity utilisation in & $(-0.16)$ & $(2.33)$ & $(-1.72)$ & $(-0.37)$ \\
manufacturing sector & 0.069 & $-0.242^{*}$ & 0.199 & $0.246^{*}$ \\
Unemployment rate & $(0.59)$ & $(-2.14)$ & $(1.65)$ & $(2.06)$ \\
& -0.148 & 0.098 & 0.064 & -0.046 \\
\hline
\end{tabular}

Notes: Students' t-statistics reported in parentheses. * means significant at 0.1 .

Source: Own calculation.

pass filter (CF; Christiano-Fitzgerald 2003), and the high-pass filter (HP; Hodrick-Prescott 1997). We used the CF filter results to estimate the non-parametric spectra. ${ }^{4}$ The results were consistent with those obtained using the parametric approach. However, the UCM results were more robust. They produced less volatile estimates at the ends of the time series and the outliers were eliminated (see Durbin - Koopman 2012). The mean duration of the cycle was 3-5 years according to the CF filtering and spectral density estimates. ${ }^{5}$ The cyclical components, resulting from a CF filter, usually had a higher amplitude than those from the UCM estimates. In the UCM estimates, the contribution of the other components to the variance of the variables was generally higher.

We computed the correlation coefficients between the cyclical components of the respective activity rates, the discouraged worker indices, and the variables characterising the macroeconomic situation (Table 3). The results differed when we accounted for lags in the variables. The female activity rate was procyclical with respect to GDP, but counter-cyclical with respect to GDP ${ }_{-1}$. It was simultaneously counter-cyclical with respect to the capacity utilisation in the manufacturing sector (coincident and lagged values). The female discouraged worker rate was procyclical with respect to the capacity utilisation in the manufacturing sector (only coincident values). The male discouraged worker rate was (statistically significant at the $10 \%$ significance level) counter-cyclical with respect to GDP. Some other statistically significant correlations coefficients appeared also for higher

$4 \quad$ Detailed results can be provided by the authors upon request.

5 The mean duration of a cycle corresponds to the periodicity, for which the estimated spectrum exhibits a global maximum. It indicates the harmonic with the highest impact on the variance of a particular time series. 
lags. The GDP and capacity utilisation in the manufacturing sector behaved independently. The unemployment rate was counter-cyclical with respect to GDP.

In the next step, we estimated the co-spectra between either the activity rates or the discouraged worker rates and the macroeconomic indicators. We used them to calculate coherency as a measure of the relation's "strength" and phase shift, which shows leads or lags between the analysed variables, both as the functions of periodicity (Harvey 1975).

We computed the squared coherency coefficients between the cyclical components of the macroeconomic indicators and the cyclical components of the respective activity rates. They were calculated on the basis of the CF business cycle estimates and were quite low, although there were a few noticeable exceptions. The estimated co-spectra indicated that there was a negative relation between GDP and male activity rate. The cycles of these variables experienced squared coherency at the level of 0.4 in 3-4-year periods. The visible and positive relation (squared coherency coefficient equal to 0.4 ) occurred between the female activity rate and the unemployment rate at their business cycle frequencies (3-5-year periods). In higher (over 5 years) business cycle periodicity, squared coherency between the cycles of unemployment rate and the female discouraged worker rate equalled 0.4 and the relation was negative. Their male counterparts experienced a slightly lower coherency value, but also with the negative relation.

\section{TEMPORAL VARIABILITY IN THE LABOUR FORCE PARTICIPATION RATES}

We performed the band spectrum regression at the business cycle frequencies in the form ${ }^{6}$ proposed by Benati (2001). Logarithms of GDP, capacity utilisation in the manufacturing sector, or unemployment rate were the regressors. We report only the slope coefficients; the constants in regressions were insignificantly different from zero. Table 4 presents the estimation results.

The estimates confirmed the existence of the added worker effect. Female participation rate was counter-cyclical with respect to capacity utilisation in the manufacturing section and procyclical with respect to the unemployment rate. Male participation rate was counter-cyclical with respect to capacity utilisation in the manufacturing sector. The discouraged worker index was procyclical for both

${ }^{6}$ Benati (2001) analyses the behaviour within the business cycle frequency band of the "not in the labour force" series using the band spectrum regression and band-pass filtering technique. He uses the frequency-domain (FD) filter used in Englund et al. (1992) and Hassler et al. (1994). 
Table 4. Band-spectrum regression slope coefficients

\begin{tabular}{lcccc}
\hline & $\begin{array}{c}\text { Male activity } \\
\text { rate }\end{array}$ & $\begin{array}{c}\text { Female } \\
\text { activity rate }\end{array}$ & $\begin{array}{c}\text { Male } \\
\text { discouraged } \\
\text { worker rate }\end{array}$ & $\begin{array}{c}\text { Female } \\
\text { discouraged } \\
\text { worker rate }\end{array}$ \\
\hline GDP & 0.090 & -0.161 & -0.031 & -0.063 \\
Capacity utilisation in the & $(1.572)$ & $(-0.915)$ & $(-0.632)$ & $(-0.866)$ \\
manufacturing sector & $-0.078^{*}$ & $-0.188^{*}$ & $0.032^{*}$ & $0.042^{*}$ \\
Unemployment rate & $(-4.156)$ & $(3.503)$ & $(2.233)$ & $(1.947)$ \\
& -0.012 & $0.163^{*}$ & 0.001 & 0.004 \\
& $(-0.500)$ & $(3.137)$ & $(0.034)$ & $(0.151)$ \\
\hline
\end{tabular}

Notes: Students' t-statistics reported in parentheses. * means significant at 0.1 .

Source: Own calculation.

Table 5. Comparison of four unobserved component models of the activity rate in Poland

\begin{tabular}{lcccccc}
\hline Model & $\mathrm{T}$ & $\mathrm{p}$ & $\begin{array}{c}\text { Log- } \\
\text { Likelihood }\end{array}$ & SC & HQ & AIC \\
\hline Basic model with stochastic cycle & 80 & 6 & 416.50 & -10.08 & -10.19 & -10.26 \\
Unemployment - fixed coefficient & 80 & 4 & 414.91 & -10.15 & -10.22 & -10.27 \\
Unemployment - random walk coefficient & 80 & 3 & 417.47 & -10.22 & -10.29 & -10.34 \\
Unemployment - smooth spline coefficient & 80 & 3 & 407.49 & -9.97 & -10.04 & -10.09 \\
Unemployment - return to normality AR(1) & 80 & 3 & 393.99 & -9.58 & -9.67 & -9.72 \\
\hline
\end{tabular}

Source: Own calculation.

sexes with respect to capacity utilisation in the manufacturing sector. Females' indicators experienced greater cyclical sensitivity with respect to the particular variables.

We extended the univariate unobserved component model of the participation rate and added the unemployment rate to the specification. The preliminary analysis produced comparable results for males and females, thus we modelled the overall participation rate (jointly for males and females). The basic model specification included the local linear trend with the stochastic cycle and two interventions. Once we added the unemployment rate to the model specification, the results improved (Table 5). The model that contained the unemployment rate and excluded the cycle ${ }^{7}$ produced better estimates according to the information criteria. The unemployment rate was statistically significantly related to the ac-

The cyclical component is excluded, but the interventions remain in the specification. The activity rate is modelled via the trend specification and the unemployment rate as the exogenous variable. 

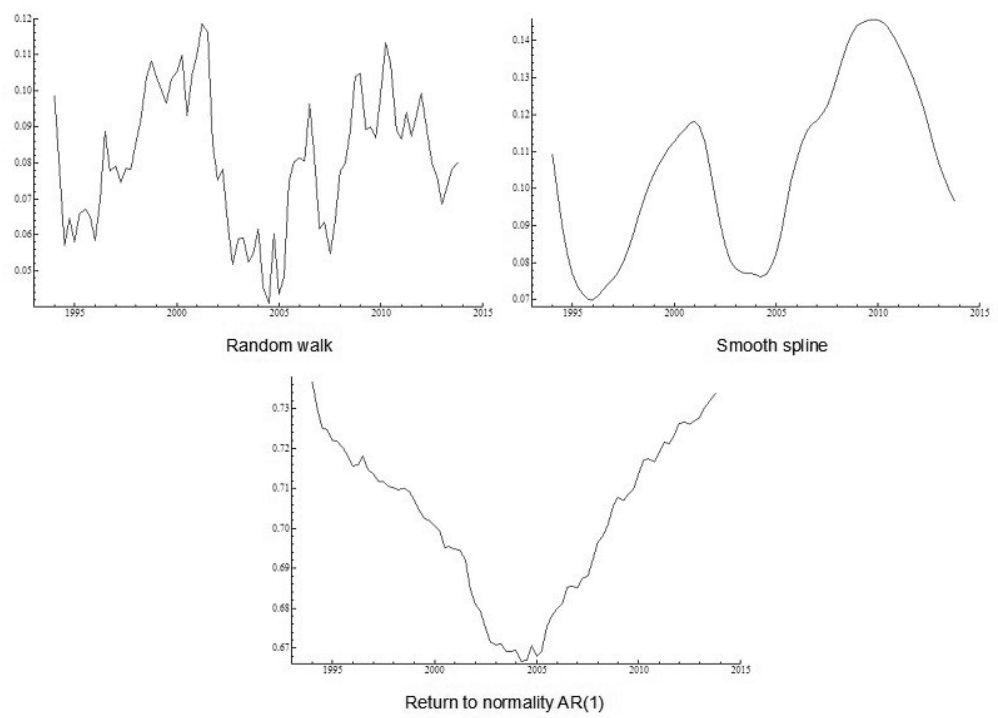

Figure 4. The varying coefficient of the unemployment rate in the models of the activity rate

Source: Own calculation.

tivity rate. If the unemployment rate rose by 1 percentage point, the activity rate increased by 0.11 percentage points. In another specification, we assumed that the unemployment rate coefficient could vary across time according to the random walk process. The varying relation between the unemployment rate and the activity rate could also be specified by assuming a gradual change of the coefficient value to present the smooth spline or by the AR(1) process. However, these specifications were less accurate according to the information criteria.

The varying unemployment rate coefficients according to the three processes are presented in Figure 4. The AR(1) process produced diminishing effect of the unemployment rate on the activity rate before 2005 . Since then, this influence has begun to increase (although the coefficient remained statistically insignificant). The smooth spline and random walk coefficients produced comparable results; however, the random walk estimates were more accurate. The influence of the unemployment rate was negatively related to the business cycle. It increased during contractions (observable in the early and late 2000s) and it decreased during expansions (experienced around 1995, 2005 and after the world crisis, which began in 2007). The coefficient oscillated between 0.04 in the economic expansions and 0.12 in the economic contractions. The changes in the coefficient were lagged compared to the changes in the cyclical unemployment. 


\section{DISCUSSION}

We found a weak, but statistically significant relation between the participation rates of the working age population and the macroeconomic indicators in the business cycle. Females' and males' participation rates generally experienced long-lasting one-directional changes. There was, however, one component of the activity rates that fell into the business cycle frequency and it implied that females behaved more cyclically than males. The short-run choices of males were predictable. Females' activity rate fluctuated very irregularly. An average cycle of the activity rates and the discouraged worker index lasted 3-5 years.

The results indicated the relation between the cyclical components of either the labour market participation rates or the discouraged worker index and the macroeconomic indicators. We found evidence that the added worker effect prevailed over the discouraged worker effect. When GDP cyclical component increased, males' and females' participation rates decreased. The data on the relative number of discouraged workers showed that this effect was quite small for females, but larger for males. Both parametric and non-parametric approaches confirmed the general evidence of the added worker effect.

Spectral analysis revealed that in the case of 3-5-year cycles, activity rates were negatively correlated to the business cycle. Thus, the added worker effect prevailed over the discouraged worker effect for both females and males. The fluctuations of this length prevailed in the business cycle frequencies and this behaviour is attributed to the deviation cycles. Over 5-year cycles, i.e. the ones from the lower business cycle frequencies (classical cycles), produced a prevalence of the discouraged worker effect. This means that discouragement occurs when ground-breaking fluctuations hit the labour force. In the presence of the less profound ones, the added worker effect prevails.

We found non-linearity in the added worker effect. Unemployment rate was positively related to the activity rate, but its influence was negatively related to the business cycle. The impact increased during recessions and decreased during economic growth. This conclusion and the finding that the activity rates experience one-directional very long changes imply some asymmetry in the nature of the added worker effect. It affects the labour force participation more in contractions than in expansions.

We proved the added worker effect for males and females. The literature usually assigns these phenomena to the "secondary workers" (Lundberg 1985), even though empirical findings are more complex. For example, Martin Roman - Moral del Blas (2002) found the discouraged worker effect for females in Germany, Spain, and the United Kingdom, but the added worker effect for females in France. Filatriau - Reynes (2012) found that the added worker effect dominates 
the discouraged worker effect for prime and middle age females in, among others, continental Europe. Fuchs - Weber (2013) found both the discouraged and added worker effects, although detailed results differ among various age-sex groups. Finally, Congregado et al. $(2011,2014)$ tested for the discouraged and added worker effect in the Spanish labour market by referring to potential non-linearities. They found a linear discouraged worker effect for males and a non-linear added worker effect for females. They argued that the added worker effect works up to a certain level of unemployment. Various analyses indicate that the prevalence of the discouraged or the added worker depends on socio-economic characteristics. Lee - Parasnis (2014), in turn, found that the discouraged worker effect dominates in developed countries, whereas the added worker effect in developing countries. If this is the case, it would suggest that Polish economy is still in transition to a fully market-oriented economy, at least in terms of the labour market.

We believe that the added worker effect in Poland can be traced to a few specific reasons. The data indicated that in Poland both sexes have similar work-leisure preferences during the business cycle. Thus, the "traditional" family model could have evolved and both spouses are equally responsible for raising income in the household. Our finding can also stem from the market-related factors. Reallocation processes and sectoral shifts are constantly present in the economy. Thus, participation rates can reflect an adjustment process in the employment structure. Similar findings were made for Ireland by Duvvury - Finn (2014). They proved that males' and females' participation rates differed during the recent recession in Ireland, although the strongest evidence of the added worker effect was found for older married females.

In the future, we plan to expand the research in a few ways. We want to repeat the analysis in the age and sex breakdown. It might produce alternative conclusions, as particular labour force sub-groups may behave differently in the labour market. We also believe that an application of the multivariate models can shed some light on this topic in the future when longer time series are available.

\section{CONCLUDING REMARKS}

The discouraged worker effect implies certain cyclical properties of the activity rates with respect to the macroeconomic indicators (either pro-cyclicality with respect to the macroeconomic activity or counter-cyclicality with respect to the unemployment rate). The added worker effect should provide contrary findings. This second effect occurs when a person enters the labour market in response to the partner's job loss. We analyse this topic at the aggregate level. We base quantitative analysis on the macroeconomic Labour Force Survey's data for males and 
females in the working age in the time period 1994-2013. The properties of the activity rates differ along the analysed periodicity. This proves that the employed methods allow for an accurate analysis of the effects.

The results show that during the cyclical downturns people in the working age entered the labour market, but left it during a period of lower unemployment. In the main business cycle frequencies, the added worker effect prevailed over the discouraged worker effect for both sexes. The added worker effect was significant and varied over time. It was considerably stronger in contractions than in the economic expansions. Usually, the literature suggests that the discouraged worker effect prevails (McConnell et al. 2006). Although the added worker effect prevailed, we found some evidence of the heterogeneity of labour force behaviour across business cycle frequencies. In lower business cycle frequencies, the discouraged worker effect was significant. This means that during profound expansions and recessions, the labour force was more prone to leaving than entering the labour market. Such situations are considerably less common than the ones in which the added worker effect prevails.

The presence of the added worker effect for both sexes suggests certain policy recommendations. New market entries during economic downturns can increase unemployment if the job search is unsuccessful. The decrease in the labour market participation occurs during the economic expansions, when it should be easier to find a job, meaning that it cannot be traced to discouragement. The policy measures should be primarily focused on encouraging workers to enter (permanently) the labour force. Further research in deeper age and sex disaggregation can shed more light on the properties of the analysed effects.

\section{REFERENCES}

Allison, C. - Ringold, D. (1996): Labor Markets in Transition in Central and Eastern Europe 19891995. World Bank Technical Paper, 352. Washington, D.C.

Benati, L. (2001): Some Empirical Evidence on the 'Discouraged Worker' Effect. Economics Letters, 70(3): 387-395.

Central Statistical Office (2015): Aktywność ekonomiczna ludności Polski I kwartał 2015 r. (Labour Force Survey in Poland I Quarter 2015), http://stat.gov.pl/obszary-tematyczne/rynek-pracy/pracujacy-bezrobotni-bierni-zawodowo-wg-bael/aktywnosc-ekonomiczna-ludnosci-polskii-kwartal-2015-r-,4,16.html [access: 29.09.2015].

Christiano, L. J. - Fitzgerald, T. J. (2003): The Band Pass Filter. International Economic Review, 44(2): 435-465.

Congregado, E. - Carmona, M. - Golpe, A. - van Stel, A. (2014): Unemployment, Gender and Labor Force Participation in Spain: Future Trends in Labor Market. Romanian Journal of Economic Forecasting, XVII (1): 53-66.

Congregado, E. - Golpe, A. - van Stel, A. (2011): Exploring the Big Jump in the Spanish Unemployment Rate: Evidence on an 'Added Worker Effect'. Economic Modelling, 28: 1099-1105. 
Durbin, J. - Koompan, S. J. (2012): Time Series Analysis by State Space Methods. Oxford: Oxford University Press.

Duvvury, N. - Finn, C. (2014): 'Man-Covery': Recession, Labour Market, and Gender Relations in Ireland. Gender, Sexuality and Feminism, 1(2): 59-81.

Englund, P. - Persson, T. - Svensson, L. (1992): Swedish Business Cycles: 1861-1988. Journal of Monetary Economics, 30(3): 343-371.

Filatriau, O. - Reynes, F. (2012): A New Estimate of Discouraged and Additional Worker Effects on Labor Participation by Sex and Age in OECD Countries. OFCE Document de travail, 201209.

Finegan, A. T. (1991): Discouraged Workers and Economic Fluctuations. Industrial and Labor Relations Review, 35(1): 88-102.

Fuchs, J. - Weber, E. (2013): A New Look at the Discouragement and the Added Worker Hypotheses: Applying a Trend-Cycle Decomposition to Unemployment. Applied Economic Letters, 20(15): 1374-1378.

Gałecka-Burdziak, E. (2011): Efekty discouraged workers, on-the-job search i out-of-labour force search na przykładzie polskiego rynku pracy (Discouraged Workers, On-the-Job Search and Out-of- Labour Force Search Effects on the Example of Polish Labour Market). In: Kotlorz, D. (ed.): Współczesny rynek pracy. Wybrane problemy (Contemporary Labour Market. Selected Problems). Katowice: Wydawnictwo Naukowe Uniwersytetu Ekonomicznego w Katowicach.

Gałecka-Burdziak, E. (2013): Mechanisms of Labour Market Matching of Job Seekers and Vacancies. Unpublished PhD thesis. Warsaw: Warsaw School of Economics.

Gałecka-Burdziak, E. (2015): Rezerwa siły roboczej? Aktywność ekonomiczna w Polsce (Reserve Labour Force? Labour Market Activity in Poland). Polityka Spoleczna, 42(2): 5-9.

Gong, X. (2010): The Added Worker Effect and the Discouraged Worker Effect for Married Women in Australia. IZA Working Paper, 4816.

Góra, M. (2005): Trwale wysokie bezrobocie w Polsce. Wyjaśnienia i propozycje (Persistency of High Unemployment in Poland. Reflections, Analytical Considerations and Some Suggestions). Ekonomista, 1: 27-48.

Harvey, A. C. (1975): Spectral Analysis in Economics. The Statistician, 24(1): 1-36.

Harvey, A. C. (1989): Forecasting Structural Time Series Models and the Kalman Filter. Cambridge: Cambridge University Press.

Hassler, J. - Lundvik, P. - Persson, T. - Söderlind, P. (1994): The Swedish Business Cycle: Stylized Facts over 130 Years. In: Bergström, V. - Vredin, A. (eds): Measuring and Interpreting Business Cycles. Oxford: Oxford University Press.

Hodrick, R. J. - Prescott, E. C. (1997): Postwar U.S. Business Cycles: An Empirical Investigation. Journal of Money, Credit and Banking, 29(1): 1-16.

Kucharski, L. (2002): Przeplywy sity roboczej w Polsce w latach dziewięćdziesiatych (Labour Force Flows in Poland during 1990s). Łódź: Katedra Ekonomii Uniwersytetu Łódzkiego.

Lee, G. - Parasnis J. (2014): Discouraged Workers in Developed Countries and Added Workers in Developing Countires? Unemployment Rate and Labour Force Participation. Economic Modelling, 41: 90-98.

Lundberg, S. (1985): The Added Worker Effect. Journal of Labor Economics, 3(1): 11-37.

Martin Roman, A. - Moral del Blas, A. (2002): Oferta de trabajo y desempleo en Europa: el caso de las mujeres (Job Offers and Unemployment in Europe: The Case of Women). Revista de Estudios Europeos, 30: 23-41.

McConnell, C. - Brue, S. - MacPherson, D. (2006): Contemporary Labor Economics. New York: McGrow-Hill Irwin. 
O'Brien, M. (2011): Discouraged Older Male Workers and the Discouraged Worker Effect. Australian Journal of Labour Economics, 14(3): 217-235.

Pater, R. (2014): Are There Two Types of Business Cycles? A Note on Crisis Detection. e-Finanse, 10(3): $1-28$.

Tomić, I. (2014): Regional Matching (In)efficiency on the Croatian Labour Market. Acta Oeconomica, 64(3): 287-312.

Zarnowitz, V. - Ozyildirim, A. (2006): Time Series Decomposition and Measurement of Business Cycles, Trends and Growth Cycles. Journal of Monetary Economics, 53(7): 1717-1739. 